Potravinarstvo Slovak Journal of Food Sciences vol. 14, 2020, p. 1001-1007

https://doi.org/10.5219/1447

Received: 21 August 2020. Accepted: 7 October 2020. Available online: 28 October 2020 at www.potravinarstvo.com

\title{
DIVERSITY OF WINTER COMMON WHEAT VARIETIES FOR RESISTANCE TO LEAF RUST CREATED IN THE V. M. REMESLO MYRONIVKA INSTITUTE OF WHEAT
}

\author{
Hanna Kovalyshyna, Yuliia Dmytrenko, Oksana Tonkha, Oleksandr Makarchuk, \\ Oleksandr Demydov, Oleksandr Humeniuk, Natalia Kozub, Anatolii Karelov, Igor Sozinov, \\ Mikhailo Mushtruk
}

\begin{abstract}
The results of the investigations of resistance winter common wheat varieties to leaf rust are given. The high resistance to the pathogen manifest varieties that contain resistance genes: $\operatorname{Lr} 9, \operatorname{Lr} 19, \operatorname{Lr} 37, \operatorname{Lr} 42+\operatorname{Lr} 24, \operatorname{Lr} 43(\operatorname{Lr} 21+\operatorname{Lr} 39)+\operatorname{Lr} 24$, $L r 9+\operatorname{Lr} 26, \operatorname{Lr} 10+\operatorname{Lr} 24$ are ascertained. The genes $\operatorname{Lr} 13, \operatorname{Lr} 34, \operatorname{Lr} 37$ in combination with other resistance genes provides long-term protection to leaf rust wheat. Winter wheat varieties, created at the V. M. Remeslo Myronivka Institute of Wheat, contain resistance genes $\operatorname{Lr} 23, \operatorname{Lr} 24, \operatorname{Lr} 26, \operatorname{Lr} 34$. The varieties Vesta, Snizhana, Demetra are protected by the resistance genes $L r 26+L r 34$, variety Zolotokolosa- Lr24 + Lr34, Ekonomka - Lr3 + Lr26, Myronivska storichna - Lr3 + Lr23 + $L r 10+\operatorname{Lr} 26$. The allele Lr34 (+) is contained in varieties: Kryzhynka, Vesta, Snizhana, Volodarka, Demetra, Vdiachna, Pamiati Remesla, Sviatkova, Podolianka, Berehynia myronivska, MIP Dniprianka, and Balada myronivska. Sustainability is an important element of an integrated system of plant protection against many diseases, and to ensure increased yields it is necessary to create and distribute sustainable varieties that will be an environmentally promising way to develop the agro-industrial complex of Ukraine.
\end{abstract}

Keywords: common winter wheat; breeding; variety; resistance; rust; genes

\section{INTRODUCTION}

The leaf rust (Puccinia recondita $f$. sp. tritici Rob. Ex Desm.) is one of the most common and harmful wheat diseases. The disease leads to significant losses of grain yield (Novohatka, 1979). The level of wheat yields loss to $30 \%$ during the epiphytotic rust according to the Food and Agriculture Organization of the United Nations (FAO) (El-Khoury, 2009). The population of the pathogen Puccinia recondita differs from the high adaptive ability. High variability virulence of the fungus leads to the accumulation of pathogens that capable of the genes of wheat resistance (Palamarchuk et al., 2019).

The most justified, economically sound, and environmentally safe method of fighting to disease is to creating resistance varieties. The effectiveness of breeding to rust resistance can be improved by using different $\mathrm{Lr}-$ genes (Zheplinska et al., 2019).

More than 90 resistance genes to the rust-leaf pathogen are identified and characterized by chromosomal localization and efficiency at the wheat genome and its relatives (Kovalyshyna and Dmytrenko, 2017), which information is collected annually and is published in the Catalogue of gene symbols for wheat (McIntosh et al., 2003a; McIntosh et al., 2007b; McIntosh et al., 2008c;
McIntosh et al., 2009d; McIntosh et al., 2010e; McIntosh et al., 2011f; McIntosh et al., 2012g; McIntosh et al., 2014h; McIntosh et al., 2016i; McIntosh et al., 2017j; McIntosh et al., 2018k; McIntosh et al., 2019l). Most genes of resistance to rust causative agents identified in cultivars of wheat descend from their wild relatives. Thus, according to the information provided in the catalogs of genetic symbols, about half of the known resistance genes to leaf rust are allogenic, introgressive into Triticum aestivum species from different types of wheat, aegilops, wheat grass, and others (Leonova et al., 2013). The almost all effective rust resistance genes at the territory of Ukraine, except $\mathrm{Lr} 10$ and $L r 23$, are allogenic, transferred to Triticum aestivum from other species: Aegilops speltoides - Lr28, Lr35, Lr36, Lr47, Lr51, Lr66; Aegilops tauschii - Lr1, Lr21, Lr22a, Lr32, Lr39, Lr42; Triticum timopheevii - Lr18, Lr50; Thinopyrum elongatum - Lr19, Lr29, Lr24; Secale cereale - Lr25, Lr26, Lr45; Aegilops umbellulata-Lr19, Lr76; Triticum spelta - Lr44, Lr65, Lr71; Triticum dicoccoides - Lr53, Lr64; Aegilops triuncialis - Lr58, LrTr; Triticum timopheevii spp. viticulosum - LrTt1; Aegilops ventricosa - Lr37; Aegilops kotschyi - Lr54; Elymus trachycaulis - Lr55; Aegilops sharonensis - Lr56; 
Aegilops geniculate - Lr57; Aegilops peregrine - Lr59; Triticum turgidum - Lr61; Aegilops neglecta - Lr62; Triticum monococcum - Lr63. Therefore, in breeding must be taken into account the fact that in the wheat genome the effective $L r$-genes are introduced not in its "pure" form, but closely linked with other genes that are undesirable to use in breeding (Dinh et al., 2020; Lodgering et al., 1970).

It is a rather difficult task creating such varieties, and over time, they lose their resistance by the emergence of new races, pathogenic strains, and climatic changes. Trends in climate warming affect on the deterioration of the phytosanitary condition of crops (Mushtruk et al., 2020).

\section{Scientific hypothesis}

The scientific hypothesis is founded on identifying nature inheritance and manifest resistance genes to exciter of leaf rust. It is attaining by investigation of composition population exciter of disease and identifies resistance genes at collectible samples soft wheat. It is making it possible to increase the resistance gene pool and creating new heterogeneous varieties of soft wheat.

\section{MATERIAL AND METHODOLOGY}

The assessment varieties (Table 1) of winter wheat were created at the V. M. Remeslo Myronivka Institute of Wheat for resistance to leaf rust made in conditions of the artificial infectious background of the wheat pathogen. Experiments were in the field conditions at a field infectious nursery of the Plant Protection Department of the V. M. Remeslo Myronivka Institute of Wheat. The climate is temperate continental. The average annual air temperature is $7.6^{\circ} \mathrm{C}$. The sum of effective temperatures above $5{ }^{\circ} \mathrm{C}$ is $3000{ }^{\circ} \mathrm{C}$. The duration of the frost-free period becomes an average of 165 days. The average annual amount of decline is $310-570 \mathrm{~mm}$.

A suspension of a mixture of spores isolated from the local leaf rust population was used for inoculation. Wheat varieties were inoculated a mixture of spores with talc in the ratio of 1:100 by a technique of Geshele (1971) in a tubing phase - beginning form ears in condition artificial infectious nursery. The spore load was $0.015 \mathrm{~kg}$ of urediniospores per one $\mathrm{m}^{2}$ of sowing. The assessment of resistance was conducted dynamically every 10 days (Tkachyk, 2014). The variety Myronivska 10 was used as a susceptible standard. The accounts defeat by the causative agent were evaluated on the scale according to Trybel et al. (2010) and Bober et al. (2020). A DNA was isolated from weight $25-40 \mathrm{mg}$ of the plant material, obtained by grinding of 5 grains in ceramic mortars to a homogeneous powder and the further selection and weighing (Babaiants, 2011). DNA isolation was conducted using sets of Diatom ${ }^{\mathrm{TM}}$ DNA Prep100 (NEOGENE, Ukraine) according to a standard procedure with certain modifications (Trybel et al., 2010).

The caSNP12 marker was used in investigations of genetic material for identification allelic status of the resistance gene to wheat leaf rust Lr34, (Radchenko and Odintsova, 2008). PCR was performed on the amplifier GeneAmp ${ }^{\circledR}$ PCR System 2720 (Thermo Fisher Scientific,
Massachusetts, USA) using sets GenPak ${ }^{\circledR}$ PCR Core according to the manufacturer's method. The primer sequences are as follows: for caSNP12F 5'-TCCCCAGTTTAACCATCCTG-3'; for caSNP12R 5'-CATTCAGTCACCTCGCAGC-3' (NEOGENE, Ukraine).

The conditions of the PCR were in line with the requirement recommended by the developer. As a result of PCR with a mixture of primers flanking the caSNP12 marker (Strahov, 1951). The stable allelic state of the markers $(-\operatorname{Lr} 34+)$ answered amplicons with a length of $234 \mathrm{p}$. n., the sensitivity was the absence of amplicons (Vyerchenko et al., 2019).

Fragments received from PCR were separated in $1.8 \%$ agarose gel. Ethyl bromide was used as an intercalating agent for DNA monitoring in an ultraviolet. The system VISION Gel (Scie-plas, Great Britain) was used for gel documentation. The length of the clearest and reproducible bands was determined using DNA marker O'Gene Ruler 50 bp Plus DNA Ladder (Fermentas, Lithuania).

\section{Statistical analysis}

To obtain information on the number and interaction of resistance genes, the obtained ratios of classes of resistant and susceptible plants (actual) were compared with one of the theoretically expected cleavages using the chi-square $\left(\chi^{2}\right)$ correspondence criterion. The assumption that the difference between the actually obtained and theoretically expected splits is random was rejected if $\chi^{2}$ fact. exceeded the critical $\chi_{\text {st. }}^{2}\left(\chi^{2} 0.05=3.84\right)$. An error of results in statistical analysis $p=0.05$. Statistical processing was performed in Microsoft Excel 2016 using the analytical application XLSTAT from Addinsoft for Microsoft Excel. Values were estimated using mean and standard deviations.

\section{RESULTS AND DISCUSSION}

The genes of high efficiency against the pathogen are $L r 9, L r 19, L r 37, L r 42+L r 24, L r 43(\operatorname{Lr} 21+\operatorname{Lr} 39)+L r 24$, $L r 9+L 26, \quad L r 10+L r 24$ discovered by investigation the population of leaf rust on varieties of carriers of effective resistance genes (Leary et al., 2018; Ramanathan et al., 2018). The resistance of the varieties protected by the $\operatorname{Lr} 24$ genome is lost. We observed a slight defeat by the pathogen of the carriers of the $\operatorname{Lr} 19$ gene, indicating that the population has virulent clones against it. The pustules of leaf rust were marked also on varieties protected by the genome $\operatorname{Lr} 9$ in some years. The genes $L r 37, L r 42+L r 24$ and $L r 43(L r 21+L r 39)+L r 24$ have high efficiency in recent years. The $L r 13, L r 34, L r 37$ genes provide the longterm protection of wheat against rust in combination with other genes (Dorofee, 1972; Bharti et al., 2016). The varieties with these genes remain resistant for $20-30$ years in different countries of the world (Leppik, 1970).

10 highly resistant endemic species of wheat and its relatives with the highest immunity to rust, in particular: Triticum monococcum, T. timopheevii, T. militinae, T. Zhykovski, T. fungicidum, Haynatriticum, Aegilops umbellulata are distinguished (Varella et al., 2017; Jafary, Szabo and Niks, 2006). 
Table 1 Genetic diversity of winter wheat varieties for resistance to leaf rust.

\begin{tabular}{|c|c|c|c|c|c|c|}
\hline Variety & & $\begin{array}{l}\text { Owner of } \\
\text { Variety }\end{array}$ & $\begin{array}{l}\text { Entry into the State } \\
\text { Register, year }\end{array}$ & $L r$-genes & $\begin{array}{l}\text { Plant damage, } \% \text {, } \\
\text { the average for } \\
2015-2018 \mathrm{pp} .\end{array}$ & $\begin{array}{c}\text { Resistance, } \\
\text { number }\end{array}$ \\
\hline Ukrainka 0246 & & MIW $^{1}$ & 1929 & $\operatorname{Lr16}$ & 13.8 & 6 \\
\hline Myronivska 264 & & MIW & 1960 & Lr3, Lr16 & 9.5 & 7 \\
\hline Myronivska 808 & & MIW & 1963 & $\operatorname{Lr} 3$ & 17.5 & 5 \\
\hline Myronivska 61 & & MIW & 1989 & $\operatorname{Lr} 26$ & 11.3 & $6-7$ \\
\hline Myronivska 27 & & MIW & 1992 & $\operatorname{Lr} 26$ & 8.3 & 7 \\
\hline Myrleben & & MIW & 1993 & $\operatorname{Lr} 26$ & 18.3 & 5 \\
\hline Myronivska 28 & & MIW & 1994 & $\operatorname{Lr} 26$ & 4.5 & 8 \\
\hline Myronivska 30 & & MIW & 1995 & $\operatorname{Lr} 26$ & 18.8 & 5 \\
\hline Myronivska 31 & & MIW & 1997 & $\operatorname{Lr} 26$ & 7.5 & 7 \\
\hline Myronivska 33 & & MIW & 1998 & $\operatorname{Lr} 26$ & 11.3 & $6-7$ \\
\hline Myrych & & MIW & 1999 & $\operatorname{Lr} 26$ & 10.0 & 7 \\
\hline Myronivska 65 & & MIW & 2000 & $\operatorname{Lr} 26$ & 16.3 & 6 \\
\hline Kryzhynka & & MIW & 2002 & $\operatorname{Lr} 26, \operatorname{Lr} 34$ & 8.3 & 7 \\
\hline Myronivska 67 & & MIW & 2002 & $\operatorname{Lr} 26$ & 15.0 & $6-7$ \\
\hline Kolumbiia & & $\mathrm{IPPG}^{2}, \mathrm{MIW}$ & 2003 & $\operatorname{Lr} 24$ & 2.8 & 8 \\
\hline Podolianka & & IPPG, MIW & 2003 & $\operatorname{Lr} 34$ & 11.3 & $6-7$ \\
\hline Snizhana & & MIW, IPPG & 2004 & $\operatorname{Lr} 26, \operatorname{Lr} 34$ & 10.0 & 7 \\
\hline Pereiaslavka & & IPPG, MIW & 2004 & Lr26 & 13.8 & 6 \\
\hline Smuhlianka & & IPPG, MIW & 2004 & $\operatorname{Lr} 24$ & 4.5 & 8 \\
\hline Demetra & & MIW, IPP 3 & 2005 & $\operatorname{Lr} 26, \operatorname{Lr} 34$ & 15.0 & $6-7$ \\
\hline Vesnianka & & IPPG, MIW & 2005 & $\operatorname{Lr} 24$ & 5.3 & 8 \\
\hline Volodarka & & IPPG, MIW & 2004 & $\operatorname{Lr} 34$ & 5.0 & 8 \\
\hline Favorytka & & IPPG, MIW & 2005 & $\operatorname{Lr} 26$ & 5.0 & 8 \\
\hline Pyvna & & IPPG, MIW & 2006 & $\operatorname{Lr} 26$ & 12.5 & $6-7$ \\
\hline Zolotokolosa & & IPPG, MIW & 2006 & $\operatorname{Lr} 24, \operatorname{Lr} 34$ & 12.5 & $6-7$ \\
\hline Kalynova & & MIW, IPPG & 2008 & $\operatorname{Lr} 26$ & 20.8 & 5 \\
\hline $\begin{array}{l}\text { Kolos } \\
\text { Myronivschyny }\end{array}$ & & MIW, IPPG & 2008 & $\operatorname{Lr} 26$ & 13.8 & $6-7$ \\
\hline Monotyp & & MIW, IPPG & 2008 & $\operatorname{Lr} 26$ & 7.5 & 7 \\
\hline Ekonomka & & MIW, IPP & 2008 & $\operatorname{Lr} 3, \operatorname{Lr} 26$ & 5.0 & 8 \\
\hline Pamiati Remesla & & MIW, IPPG & 2009 & $\operatorname{Lr} 34$ & 5.8 & 7 \\
\hline $\begin{array}{l}\text { Myronivska } \\
\text { storichna }\end{array}$ & & MIW, IPP & 2009 & $\operatorname{Lr} 3, \operatorname{Lr} 10, \operatorname{Lr} 23, \operatorname{Lr} 26$ & 5.8 & 7 \\
\hline $\begin{array}{l}\text { Yuviliar } \\
\text { Myronivskyi }\end{array}$ & & MIW, IPPG & 2009 & & 12.5 & $6-7$ \\
\hline Myrliena & & MIW, IPPG & 2009 & $\operatorname{Lr} 23$ & 5.8 & 7 \\
\hline Yasnohirka & & IPPG, MIW & 2009 & $\operatorname{Lr} 24$ & 4.0 & 8 \\
\hline Slavna & & IPPG, MIW & & $\operatorname{Lr} 24$ & 8.9 & 7 \\
\hline Yavoryna & & IPPG & 2010 & $\operatorname{Lr} 24$ & 10.0 & 7 \\
\hline $\begin{array}{l}\text { Lehenda } \\
\text { Myronivska }\end{array}$ & & MIW & 2012 & $\operatorname{Lr} 26$ & 10.0 & 7 \\
\hline $\begin{array}{l}\text { Myronivska } \\
\text { (standard } \\
\text { susceptibility) }\end{array}$ & $\begin{array}{l}10 \\
\text { of }\end{array}$ & MIW & & & 26.3 & $3-4$ \\
\hline
\end{tabular}

Note: 1 MIW - the V. M. Remeslo Myronivka Institute of Wheat of the National Academy of Agrarian Sciences of Ukraine; 2 IPPG - Institute of Plant Physiology and Genetics of the National Academy of Sciences of Ukraine; 3 IPP Institute of Plant Protection of the National Academy of Agrarian Sciences of Ukraine.

In the works (Casey et al., 2016; Marryat, 1907; Davoyan et al., 2012) found forms immune to rust, powdery mildew, and soot among Triticum dicoccum.

The principles of researching gene pool of wheat resistance against leaf rust, based on (Flor, 1971) theory of "gene-for-gene", developed (Berlyand-Kozhevnikov et al., 1985).

In Ukraine, wheat breeding for rust resistance is conducted for more than 40 years. Scientific researches on the study of genetic signs of resistance to the causative agent of leaf rust actively unfolded in the late 70's - the early 80 's of the twentieth century (Morgounov et al., 2011). The greatest successes have been achieved at the $V$. M. Remeslo Myronivka Institute of Wheat of the National Academy of Agricultural Sciences of Ukraine, the Plant Breeding and Genetics Institute - National Center of Seed and Cultivar Investigation of the National Academy of Agricultural Sciences of Ukraine, the Institute of Plant Protection of National Academy of Agrarian Sciences of Ukraine and the Plant Production Institute nd. a. V. Ya. Yuryev of National Academy of Agrarian Sciences of Ukraine (Khaneghah et al., 2018; Kirilenko, 2014).

We conducted researches on the detection of the resistance gene to leaf rust in winter wheat varieties of Myronivka's breeding. The $1 B L / 1 R S$ wheat-rye translocation, which carries the resistance gene to leaf rust Lr26, as well as resistance genes to stem rust Sr31, powdery mildew Pm8, yellow rust Yr9 were found in the following varieties: Myronivska 61, Myronivska 27, Myrleben, Myronivska 28, Myronivska 30, Myronivska 31, Myronivska 33, Myrych, Myronivska 65, Myronivska 66, Kryzhynka, Myronivska 67, Vesta, Snizhana, 
Table 2 Allelic status of the Lr34 gene in new winter wheat varieties of MIW by results of PCR on the marker caSNP12, 2017.

\begin{tabular}{lcc}
\hline \multicolumn{1}{c}{ Variety } & Entry into the State Register, year & Allelic status of the gene Lr34* \\
\hline Svitanok Myronivskyi & 2014 & - \\
Horlytsia myronivska & 2016 & - \\
Hospodynia myronivska & 2017 & + \\
Berehynia myronivska & 2016 & - \\
MIP Kniazhna & 2017 & - \\
MIP Vyshyvanka & 2017 & - \\
MIP Valensiia & 2017 & - \\
Myronivska slava & 2017 & - \\
Trudivnytsia myronivska & 2017 & - \\
Estafeta myronivska & 2018 & - \\
Vezha myronivska & 2018 & + \\
MIP Dniprianka & 2018 & + \\
Balada myronivska & 2018 & - \\
Hratsiia myronivska & 2018 & - \\
MIP Assol & 2018 & - \\
\hline Note: $*$ "+ - Associated with allele resistance $L r 34(+) ; "-"$ allele present in susceptible varieties Lr34 (-).
\end{tabular}

Pereiaslavka, Demetra, Favorytka, Pyvna, Kalynova, Kolos Myronivschyny, Monotyp, Ekonomka, Myronivska storichna, Lehenda Myronivska according to the results of investigations by Kovalyshyna et al. (2020), Lisova (2012) and You-Xiong et al. (2009). The Lr26 gene does not provide high resistance of varieties to leaf rust causative agent, since this gene has lost its effectiveness against the population of the disease as the data in Table 1 show.

The availability of wheat-rye translocation $1 A L / 1 R S$ in the genotype of winter wheat provides resistance to fungal diseases, because it carries a complex of resistance genes to leaf rust $L r 24$, stem rust $S r 1 R S$, powdery mildew $P m 17$. This translocation was detected in varieties: Kolumbiia, Smuhlianka, Vesnianka, Zolotokolosa, Yasnohirka, Slavna, Yavoryna (Vlasenko, Koliuchyi and Chebakov, 2005; Landjeva et al., 2006). The Lr24 gene provides moderate resistance to leaf rust, varieties have damage of $2.8-17.2 \%$.

The varieties Vesta, Snizhana, Demetra are protected by the $\operatorname{Lr} 26$ and $L r 34$ genes, and the Zolotokolosa - by the Lr24 and Lr34. The combination of these resistance genes inhibits the development of leaf rust on winter wheat varieties, damage of the leaf surface is within $10-17.5 \%$

The Myrliena variety contains the gene $L r 23$, and the Myronivska storichna - Lr3, Lr23, Lr10, and Lr26 are ascertaining according to the analysis of the genealogy of varieties. The Lr3, Lr24 genes, protects the Ekonomka variety.

The gene Lr34, which belongs to the group of genes that provide partial resistance in the phase of adult plants, is found in the following varieties: Kryzhynka, Vesta, Snizhana, Volodarka, Demetra, Vdiachna, Pamiati Remesla, and Sviatkova (Kozub et al., 2017; Pirko et al., 2012). Eight varieties exhibit polymorphism for the gen Lr34 - Illichivka, Myronivska 30, Myronivska 32, Myronivska 65, Myronivska 66, Pyvna, Ekonomka, Lehenda Myronivska. Perhaps a small frequency of the dominant allele of the $L r 34$ gene in the varieties of MIW is related to the difficulty of identifying it in field conditions in the Right-Bank Forest-Steppe zone of Ukraine with the use of classical breeding methods, since for varieties of the Plant Breeding and Genetics Institute - National Center of
Seed and Cultivar Investigation of the National Academy of Agricultural Sciences of Ukraine frequency is much higher. The varieties Zolotokolosa and Podolianka also contain the gene Lr34 according to Radchenko and Tishchenko (2010) and Krattinger et al. (2016).

We found that among the 15 newly created varieties, only 3 varieties - Berehynia myronivska, MIP Dniprianka, and Balada myronivska contain the Lr34 allele $(+)$, which is only $20 \%$ of the investigated varieties according to the PCR results, using the caSNP12 marker (Table 2).

\section{CONCLUSION}

It has been established that effective against the pathogen of leaf rust the are genes: $\operatorname{Lr} 9, \operatorname{Lr} 19, \operatorname{Lr} 37, \operatorname{Lr} 42+\operatorname{Lr} 24$, $L r 43(L r 21+L r 39)+L r 24, \quad L r 9+L 26, \quad L r 10+L r 24 . \quad T h e$ genes Lr13, Lr34, Lr37 in combination with other genes, provide the long-term protection of wheat against leaf rust.

The wheat-rye translocation $1 B L / 1 R S$ was identified in the following varieties: Myronivska 61, Myronivska 27, Mirleben, Myronivska 28, Myronivska 30, Myronivska 31, Myronivska 33, Myrych, Myronivska 65, Myronivska 66, Kryzhynka, Myronivska 67, Vesta, Snizhana, Pereiaslavka, Demetra, Favorytka, Pyvna, Kalynova, Kolos Myronivschyny, Monotyp, Ekonomka, Myronivska storichna, Lehenda Myronivska.

The availability of wheat-rye translocation $1 A L / 1 R S$ was found in varieties: Kolumbiia, Smuhlianka, Vesnianka, Zolotokolosa, Yasnohirka, Slavna, Yavoryna.

The Lr34 (+) allele is presented in varieties: Kryzhynka, Vesta, Snizhana, Volodarka, Demetra, Vdiachna, Pamiati Remesla, Sviatkova, Podolianka, Zolotokolosa, Berehynia myronivska, MIP Dniprianka, and Balada myronivska according to the results of the research. As a result of research, it was found that the wheat variety Myronivska Ukrainian selection is quite productive in comparison with other varieties and resistant to pathogens of various diseases, especially to the pathogen (brown rust).

\section{REFERENCES}

Babaiants, O. V. 2011. Immunological characteristics of wheat plant resources and substantiation of genetic protection against pathogens of fungal aetiology in the Steppe region of Ukraine : dissertation theses. Kyiv, Ukraine : 
National University of Life and Environmental Sciences of Ukraine, 122 p.

Berlyand-Kozhevnikov, V., Mihaylova, L., Borodanenko, N. 1985. A catalog of wheat samples characterized by specific brown rust resistance genes. Lenynhrad, Rusia : Vaskhnil, $144 \mathrm{p}$.

Bharti, N., Pandey, S. S., Barnawal, D., Patel, V. K., Kalra, A. 2016. Plant growth promoting rhizobacteria Dietzia natronolimnaea modulates the expression of stress responsive genes providing protection of wheat from salinity stress. Scientific reports, vol. 6, no. 1, p. 1-16. https://doi.org/10.1038/srep34768

Bober, A., Liashenko, M., Protsenko, L., Slobodyanyuk, N., Matseiko, L., Yashchuk, N., Gunko, S., Mushtruk, M. 2020. Biochemical composition of the hops and quality of the finished beer. Potravinarstvo Slovak Journal of Food Sciences, vol.14, p. 307-317. https://doi.org/10.5219/1311

Casey, L., Lavrencic, P., Bentham, A., Cesari, S., Ericsson, D., Croll, T., Mobli, M. 2016. The CC domain structure from the wheat stem rust resistance protein Sr33 challenges paradigms for dimerization in plant NLR proteins. Proceedings of the National Academy of Sciences, vol. 113, no. $45, \quad$ p. 12856-12861. https://doi.org/10.1073/pnas.1609922113

Davoyan, E. R., Davoyan, R. O., Bebyakina, I. V., Davoyan, O. R., Zubanova, Y. S., Kravchenko, A. M., Zinchenko, A. N. 2012. Identification of a leaf-rust resistance gene in species of Aegilops L., synthetic forms, and introgression lines of common wheat. Russian Journal of Genetics: Applied Research, vol. 2, no. 4, p. 325-329. https://doi.org/10.1134/S2079059712040041

Dinh, H., Singh, D., Periyannan, S., Park, R., Pourkheirandish, M. 2020. Molecular genetics of leaf rust resistance in wheat and barley. Theoretical and Applied Genetics, vol. 133, p. 2035-2050. https://doi.org/10.1007/s00122-020-03570-8

Dorofee, V. F. 1972. Wheat of the Caucasus. Works on Applied Botany, Genetics and Selection, vol. 47, no. 1, p. 455502.

El-Khoury, W. 2009. The UN-FAO Wheat Rust Disease Global Program. In Proceedings, oral papers and posters, 2009 Technical Workshop, Borlaug Global Rust Initiative, Cd. Obregón, Sonora, Mexico : Borlaug Global Rust Initiative, p. 213-220.

Flor, H. H. 1971. Current status of the gene-for-gene concept. Annu. Rev. Phytopathol., vol. 9, p. 275-296. https://doi.org/10.1146/annurev.py.09.090171.001423

Geshele, E. E. 1971. Methodological Manual on Phytopathological Evaluation of Cereals. Odessa, UA : Izd. VSGI, 180 p. https://doi.org/10.1134/S1022795413110136

Jafary, H., Szabo, L. J., Niks, R. E. 2006. Innate nonhost immunity in barley to different heterologous rust fungi is controlled by sets of resistance genes with different and overlapping specificities. Molecular plant-microbe interactions, vol. 19, no. 11, p. 1270-1279. https://doi.org/10.1094/MPMI-19-1270

Khaneghah, A., Martins, L., von Hertwig, A., Bertoldo, R., Sant'Ana, A. 2018. Deoxynivalenol and its masked forms: Characteristics, incidence, control and fate during wheat and wheat based products processing-A review. Trends in Food Science \& Technology, vol. 71, p. 13-24. https://doi.org/10.1016/j.tifs.2017.10.012

Kirilenko, V. 2014. Traditional and modern breeding methods of Triticum aestivum L. in the VM Remeslo Myronivka Institute of Wheat. Plant varieties studying and protection, vol. 4, no. 25, p. 41-46. https://doi.org/10.21498/2518-1017.4(25).2014.55882

Kovalyshyna, H. M., Dmytrenko, Y. M. 2017. Sources of resistance to brown rust pathogen and their use in the development of soft wheat varieties. Plant Varieties Studying and Protection, vol. 13, no. 2, p. 379-386. https://doi.org/10.21498/2518-1017.13.4.2017.117742

Kovalyshyna, H., Dmytrenko, Y., Makarchuk, O., Slobodyanyuk, N., Mushtruk, M. 2020. The donor properties of resources resistance against the exciter of wheat rust wheat. Potravinarstvo Slovak Journal of Food Sciences, vol. 14, p. 821-827. https://doi.org/10.5219/1427

Kozub, N., Sozinov, I., Karelov, A., Blume, Y., Sozinov, A. 2017. Diversity of Ukrainian winter common wheat varieties with respect to storage protein loci and molecular markers for disease resistance genes. Cytology and Genetics, vol. 51, p. 117-129. https://doi.org/10.3103/S0095452717020050

Krattinger, S. G., Sucher, J., Selter, L. L., Chauhan, H., Zhou, B., Tang, M., Schaffrath, U. 2016. The wheat durable, multipathogen resistance gene Lr34 confers partial blast resistance in rice. Plant biotechnology journal, vol. 14, no. 5, p. 1261-1268. https://doi.org/10.1111/pbi.12491

Landjeva, S., Korzun, V., Tsanev, V., Vladova, R., Ganeva, G. 2006. Distribution of the wheat-rye translocation 1RS. 1BL among bread wheat varieties of Bulgaria. Plant breeding, vol. 125, no. 1, p. 102-104. https://doi.org/10.1111/j.1439-0523.2006.01142.x

Leary, A., Sanguankiattichai, N., Duggan, C., Tumtas, Y., Pandey, P., Segretin, M. E., Bozkurt, T. O. 2018. Modulation of plant autophagy during pathogen attack. Journal of Experimental Botany, vol. 69, no. 6, p. 1325-1333. https://doi.org/10.1093/jxb/erx425

Leonova, I., Badaeva, E., Orlovskaya, O., Röder, M., Khotyleva, L., Salina, E., Shumny, V. 2013. Comparative Characteristic of Triticum aestivum/Triticum durum and Triticum aestivum/Triticum dicoccum hybrid lines by genomic composition and resistance to fungal diseases under different environmental conditions. Russian Journal of Genetics, vol. 49, no. 11, p. 1276-1283. https://doi.org/10.7868/S0016675813110131

Leppik, E. E. 1970. Gene centers of plant as source of disease resistance. Ann. Rev. Phytopathol., vol. 8, p. 323-344. https://doi.org/10.1146/annurev.py.08.090170.001543

Lisova, H. M. 2012. Expression of wheat resistance genes to the the brown rust pathogen in the conditions of the ForestSteppe zone of Ukraine in 2000 - 2010. Protection and Plant Quarantine, vol. 58, p. 97-106. (in Ukrainian)

Lodgering, W. K., Johnston, C. O., Hendricks, Y. U. 1970. Wheat and its improvement. Moscow, Russia : Kolos, 379 p.

Marryat, D. C. 1907. Notes on the infection and histology of two wheats immune to the attacks of Puccinia glumarum, Yellow Rust.[With Plate II.]. The Journal of Agricultural Science, vol. 2, no. 2, p. 129-138. https://doi.org/10.1017/S0021859600001246

McIntosh, R. A., Yamazaki, Y., Devos, K. M., Dubcovsky, J., Rogers, W. J., Appels, R. 2003a. Catalogue of Gene Symbols for Wheat. Annu. Wheat Newslett., vol. 49, p. 246282.

McIntosh, R. A., Devos, K. M., Dubcovsky, J., Rogers, W. J., Morris, C. F., Appels, R., Somers, D. J., Anderson, O. D. 2007b. Catalogue of gene symbols for wheat: 2007 supplement. Annu. Wheat Newslett., vol. 53, p. 159-180.

McIntosh, R. A., Devos, K. M., Dubcovsky, J., Rogers, W. J., Morris, C. F., Appels, R., Somers, D. J., Anderson, O. D. 2008c. Catalogue of gene symbols for wheat: 2008 supplement. Annu. Wheat Newslett., vol. 54, p. 209-225. 
McIntosh, R. A., Dubcovsky, J., Rogers, W. J., Morris, C. F., Appels, R., Xia, X. C. 2009d. Catalogue of gene symbols for wheat: 2009 supplement. Annu. Wheat Newslett., vol. 55, p. 256-278.

McIntosh, R. A., Dubcovsky, J., Rogers, W. J., Morris, C. F., Appels, R., Xia, X. C. 2010e. Catalogue of gene symbols for wheat: 2010 supplement. Annu. Wheat Newslett., vol. 56, p. 273-282.

McIntosh, R. A., Dubcovsky, J., Rogers, W. J., Morris, C. F., Appels, R., Xia, X. C. 2011f. Catalogue of gene symbols for wheat: 2011 supplement. Annu. Wheat Newslett., vol. 57, p. 303-322.

McIntosh, R. A., Dubcovsky, J., Rogers, W. J., Morris, C. F., Appels, R., Xia, X. C. 2012g. Catalogue of gene symbols for wheat: 2012 supplement. Annu. Wheat Newslett., vol. 58, p. $259-279$.

McIntosh, R. A., Dubcovsky, J., Rogers, W. J., Morris, C. F., Appels, R., Xia, X. C. 2014h. Catalogue of gene symbols for wheat: 2013-2014 supplement. Annu. Wheat Newslett., vol. 60 , p. 153-175.

McIntosh, R. A., Dubcovsky, J., Rogers, W. J., Morris, C. F., Appels, R., Xia, X. C. 2016i. Catalogue of gene symbols for wheat: 2015-2016 supplement. Annu. Wheat Newslett., vol. 62 , p. 102-114.

McIntosh, R. A., Dubcovsky, J., Rogers, W. J., Morris, C. F., Appels, R., Xia, X. C. 2017j. Catalogue of gene symbols for wheat: 2017-2018 supplement. Annu. Wheat Newslett., vol. 63 , p. 107-121.

McIntosh, R. A., Dubcovsky, J., Rogers, W. J., Xia, X. C., Raupp, W. J. 2018k. Catalogue of gene symbols for wheat: 2018-2019 supplement. Annu. Wheat Newslett., vol. 64, p. 73-93.

McIntosh, R. A., Dubcovsky, J., Rogers, W. J., Xia, X. C., Raupp, W. J. 20191. Catalogue of gene symbols for wheat: 2019 supplement. Annu. Wheat Newslett., vol. 65, p. 98-109.

Morgounov, A., Ablova, I., Babayants, O., Babayants, L., Bespalova, L., Khudokormov, Z., Syukov, V. 2011. Genetic protection of wheat from rusts and development of resistant varieties in Russia and Ukraine. Euphytica, vol. 179, no. 2, p. 297-311. https://doi.org/10.1007/s10681-010-0326-5

Mushtruk, M., Vasyliv, V., Slobodaniuk, N., Mukoid, R., Deviatko, O. 2020. Improvement of the Production Technology of Liquid Biofuel from Technical Fats and Oils. In Ivanov, V., Trojanowska, J., Machado, J., Liaposhchenko, O., Zajac, J., Pavlenko, I., Edl, M., Perakovic, D. Advances in Design, Simulation and Manufacturing III. Switzerland : Springer International Publishing, p. 377-386. ISBN 21954364-21954356. $\quad$ https://doi.org/10.1007/978-3-03050491-5 36

Novohatka, V. G. 1979. Epiphytotics Puccinia recondita Rob. et Desm. f. sp. tritici on Winter Wheat in the ForestSteppe Zone of the Ukrainian SSR. Mycology and Phytopathology, vol. 13, no. 6, p. 488-493. (in Russian)

Palamarchuk, I., Mushtruk, M., Vasyliv, V., Zheplinska, M. 2019. Substantiation of regime parameters of vibrating conveyor infrared dryers. Potravinarstvo Slovak Journal of Food Sciences, vol. 13, no. 1, p. 751-758. https://doi.org/10.5219/1184

Pirko, Y., Karelov, A., Kozub, N., Sozinov, I., Pirko, N., Yemets, A., Korkhovyi, V., Koliuchyi, V., Blium, Y., Sozinov, O. 2012. Implementation of the methods for detection of leaf rust resistance genes in wheat based on carrying out polymerase chain reaction. Science and Innovation, vol. 8: p. 50-56.

Radchenko, A., Tishchenko, E. 2010 Identification of Lr34 gene resistance to the leaf rust in wheat variants, using microsatelliting marker. Bulletin of the Ukrainian Society of Geneticists and Breeders, vol. 8, p. 41-45.

Radchenko, E. E., Odintsova, I. G. 2008. Identification of genes for the resistance of crops to pests. In Radchenko, E. E. et al. Studying the genetic resources of crops for resistance to pests. Moscow, Russia : Russian Agricultural Academy, 416 p.

Ramanathan, S., Arunachalam, K., Chandran, S., Selvaraj, R., Shunmugiah, K. P., Arumugam, V. R. 2018. Biofilm inhibitory efficiency of phytol in combination with cefotaxime against nosocomial pathogen Acinetobacter baumannii. Journal of applied microbiology, vol. 125, no. 1, p. 56-71. https://doi.org/10.1111/jam.13741

Strahov, T. D. 1951. Assessment of wheat varieties by immunity and susceptibility to brown leaf rust. KHARKIV, UKRAINE : Institute of Genetics, $72 \mathrm{p}$.

Tkachyk, S. O. 2014. Methods of phytopathological research for artificial infection of plants. Kyiv, UA : N.p., 76 p. ISBN 978-617-7212-58-3

Trybel, S., Hetman, M., Stryhun, O., Kovalyshyna, H., Andriushchenko, A. 2010. Methodology of Assessing Resistance of Wheat Varieties to Pests and Pathogens. Kyiv, UA : Kolobih, 362 p. ISBN 978-966-8610-41-7

Varella, A., Weaver, D., Cook, J., Blake, N., Hofland, M., Lamb, P., Talbert, L. 2017. Characterization of resistance to the wheat stem sawfly in spring wheat landrace accessions from targeted geographic regions of the world. Euphytica, vol. 213 , no. 7 , p. 153-159. https://doi.org/10.1007/s10681$\underline{017-1945-\mathrm{X}}$

Vlasenko, V., Koliuchyi, V., Chebakov, M. 2005. Using genetic components of rye in the breeding of Myronivka varieties of winter wheat. Journal of Uman National University of Horticulture, vol. 60, p. 54-63.

Vyerchenko, L., Tkachenko, S., Sheiko, T., Kos, T., Dzhohan, O., Vasyliv, V. 2019. The study of calcium hydroxide structure and its physico-chemical and electrokinetic properties in sugar production. Chemistry and Chemical Technology, vol. 13, no. 4, p. 477-481. https://doi.org/10.23939/chcht13.04.477

You-Xiong, Q. U. E., Zhi-Xia, Y. A. N. G., Li-Ping, X. U., Ru-Kai, C. H. E. N. 2009. Isolation and identification of differentially expressed genes in sugarcane infected by Ustilago scitaminea. Acta Agronomica Sinica, vol. 35, no. 3, p. 452-458. https://doi.org/10.1016/S1875-2780(08)60068-1

Zheplinska, M., Mushtruk, M., Vasyliv, V., Deviatko, O. 2019. Investigation of the process of production of crafted beer with spicy and aromatic raw materials. Potravinarstvo Slovak Journal of Food Sciences, vol. 13, no. 1, p. 806-814. https://doi.org/10.5219/1183

\section{Contact address:}

Hanna Kovalyshyna, National University of Life and Environmental Sciences of Ukraine, Agrobiological Faculty, Department of Genetics, Plant Breeding and Seed Production them Prof. M. O. Zelensky, Heroiv Oborony Street, 13, Kyiv, 03041, Ukraine, Tel.: +38(096)410-4516 ,

E-mail: hkovalyshyna@gmail.com

ORCID: https://orcid.org/0000-0002-2715-7679

Yuliia Dmytrenko, National University of Life and Environmental Sciences of Ukraine, Agrobiological Faculty, Department of Genetics, Plant Breeding and Seed Production them Prof. M. O. Zelensky, Heroiv Oborony Street, 13, Kyiv, 03041, Ukraine, Tel.: +38(098)78-30971, 
E-mail: dmitrenko.yuliia@gmail.com

ORCID: https://orcid.org/0000-0002-3942-9125

Oksana Tonkha, Department of Soil Science and Soil

Protection them prof. M. K. Shykuly, National University of Life and Environmental Sciences of Ukraine, 17 Heroiv

Oborony Street, Kyiv 03041, Ukraine,

E-mail: oksana16095@gmail.com

ORCID: https://orcid.org/0000-0002-0677-5494

Oleksandr Makarchuk, National University of Life and Environmental Sciences of Ukraine, Agrobiological Faculty, Department of Genetics, Plant Breeding and Seed Production them Prof. M. O. Zelensky, Heroiv Oborony Street, 13, Kyiv, 03041, Ukraine, Tel.: +38(096)335-7531 ,

E-mail: mcar2010@ukr.net

ORCID: https://orcid.org/0000-0002-3348-676X

Oleksandr Demydov, The V. M. Remeslo Myronivka Institute of Wheat of the National Academy of Agrarian Sciences of Ukraine, 68 Tsentralna Street, Tsentralne, Myronivka district, Kyiv region, 08853, Ukraine,

E-mail: a.demidov@meta.ua

ORCID: https://orcid.org/0000-0002-5715-2908

Oleksandr Humeniuk, The V. M. Remeslo Myronivka Institute of Wheat of the National Academy of Agrarian Sciences of Ukraine, 68 Tsentralna Street, Tsentralne, Myronivka district, Kyiv region, 08853, Ukraine,

E-mail: alexgymenyk@ukr.net

ORCID: https://orcid.org/0000-0002-1147-088X

Natalia Kozub, Institute of Plant Protection of the National Academy of Agrarian Sciences of Ukraine, 33 Vasylkivska Street, Kyiv 03022, Ukraine, Institute of Food
Biotechnology and Genomics of the National Academy of Sciences of Ukraine, 2a Osipovskogo Street, Kyiv 04123, Ukraine,

E-mail: natalkozub@gmail.com

ORCID: https://orcid.org/0000-0002-3572-1786

Anatolii Karelov, Institute of Plant Protection of the National Academy of Agrarian Sciences of Ukraine, 33 Vasylkivska Street, Kyiv 03022, Ukraine, Institute of Food Biotechnology and Genomics of the National Academy of Sciences of Ukraine, 2a Osipovskogo Street, Kyiv 04123, Ukraine,

E-mail: tolikkarelov@meta.ua

ORCID: https://orcid.org/0000-0001-6548-2504

Igor Sozinov, Institute of Plant Protection of the National Academy of Agrarian Sciences of Ukraine, 33 Vasylkivska Street, Kyiv 03022, Ukraine, Institute of Food Biotechnology and Genomics of the National Academy of Sciences of Ukraine, 2a Osipovskogo Street, Kyiv 04123, Ukraine,

E-mail: sia1953@ukr.net

ORCID: https://orcid.org/0000-0002-3621-5746

*Mikhailo Mushtruk, National University of Life and Environmental Sciences of Ukraine, Faculty of Food Technology and Quality Control of Agricultural Products, Department of Processes and Equipment for Processing of Agricultural Production, Heroev Oborony Str., 12 B, Kyiv, 03040, Ukraine, Tel.: +38098941-26-06,

E-mail: mixej.1984@ukr.net

ORCID: https://orcid.org/0000-0002-3646-1226

Corresponding author: * 